\title{
KOMPENSASI SEBAGAI ALAT PENINGKATAN KINERJA DALAM BINGKAI AGENCY THEORY
}

\author{
Dwi Sulistiani \\ tiaraakbar2006@yahoo.com \\ Jurusan MPI FITK UIN Maulana Malik Ibrahim Malang \\ Jawa Timur, Indonesia
}

\begin{abstract}
Agency theory looked at the relationship between the owner (the principal) and management (agent). Compensation given to overcome problems in the theory of agency, ie the difference between the interests of owners and agents. Compensation system is designed organization aims to motivate employees to improve their performance and retain competent employees. In order to work incentive compensation, corporate boards must choose a level measurement and precise performance. Performance-based Reward twofold benefit: informing and motivating.

The purpose of this paper is to review how compensation as a performance enhancement tool. The research method uses literature study and its conclusions are: 1. The compensation was given to address the problems in the theory of agency (the difference between the interests of owners and agents). 2. The compensation system is designed organization aims to motivate employees to improve their performance and retain competent employees. 3. To work incentive compensation, corporate boards must choose a level measurement and precise performance. The measurement system there are two traditional compensation (use of accounting profit that measure the past) and the stock price (measuring the future).
\end{abstract}

Keywords : compensation, agency theory, performance

\section{Abstrak}

Teori keagenan memandang adanya hubungan antara pemilik (prinsipal) dan manajemen perusahaan (agen).Kompensasi diberikan untuk mengatasi masalah dalam teori agensi, yaitu perbedaan kepentingan antara pemilik dan agennya. Sistem kompensasi yang dirancang organisasi bertujuan untuk memotivasi karyawan untuk meningkatkan kinerjanya dan mempertahankan karyawan yang kompeten. Agar kompensasi insentif bekerja, corporate boards harus memilih pengukuran dan level kinerja yang tepat. Reward berbasis kinerja memberi dua manfaat : memberi informasi dan memberikan motivasi.

Tujuan makalah ini adalah mereview bagaimana kompensasi sebagai alat peningkatan kinerja. Metode penelitiannya menggunakan studi literatur dan kesimpulannya adalah: 1 . kompensasi diberikan untuk mengatasi masalah dalam teori agensi (perbedaan kepentingan antara pemilik dan agennya). 2. Sistem kompensasi yang dirancang organisasi bertujuan untuk memotivasi karyawan untuk meningkatkan kinerjanya dan mempertahankan karyawan yang kompeten. 3. Agar kompensasi insentif bekerja, corporate boards harus memilih pengukuran dan level kinerja yang tepat. Sistem pengukuran kompensasi ada dua yaitu tradisional (penggunaan accounting profit yang mengukur masa lalu) dan stock price (mengukur masa depan).

Kata kunci : kompensasi, agency theory, kinerja 


\section{Pendahuluan}

Teori keagenan memandang adanya hubungan antara pemilik (prinsipal) dan manajemen perusahaan (agen).Prinsipal mempercayai agen yang memberikan jasa manajerialnya.Dengan jasanya tersebut, agen menerima kompensasi dari prinsipal.Kompensasi memberikan imbalan atas tindakan karyawan perusahaan. Dalam beberapa dekade terakhir, terdapat banyak perusahaan yang menyadari bahwa kaitan antara kompensasi, terutama kompensasi manajemen eksekutif, dengan hasil strategis yang membangun nilai dalam perusahaan bersifat tidak pasti. Kesadaran atas ketidakpastian telah meningkatkan kesadaran akan kebutuhan untuk mengaitkan kompensasi manajemen dengan implementasi yang berhasil atas strategi yang membangun nilai pemegang saham dalam jangka panjang.

Beberapa penelitian menunjukkan adanya hubungan yang signifikan antara kompensasi manajerial dengan kinerja keuangan, kinerja pasar, dan ukuran perusahaan. Pada umumnya, rencana kompensasi didasarkan pada ukuran prestasi manajer yaitu pendapatan bersih dan harga saham (Scott, 1997). Sistem kompensasi yang dirancang organisasi bertujuan untuk memotivasi karyawan untuk meningkatkan kinerjanya dan mempertahankan karyawan yang kompeten. Karyawan perusahaan memandang masalah kompensasi sebagai sumber pendapatan, penerimaan akibat pendidikan dan keterampilan yang dimiliki serta menunjukkan kontribusi kerja mereka serta elemen utama terciptanya kepuasan kerja. Ketidakpuasan terhadap kompensasi akan mempunyai dampak pada menurunnya daya tarik pekerjaan yang berakibat perputaran karyawan. Untuk itu organisasi harus benar-benar merancang sistem kompensasi yang efisien, efektif serta dapat memastikan bahwa imbalan yang diterima oleh karyawan dapat mempengaruhi kinerjanya (performance based pay) dan menciptakan keselarasan kerja antar staf dengan pimpinan perusahaan dalam mencapai tujuan yang telah ditetapkan.

Tujuan dari makalah ini adalah membahas kompensasi eksekutif dan bagaimana kompensasi eksekutif tersebut bekerja. Kompensasi eksekutif digunakan sebagai salah satu alat dalam pendorong peningkatan kinerja.

\section{Pembahasan \\ Kompensasi}

Martoyo (2007), mendefinisikan kompensasi sebagai Pengaturan keseluruhan pemberian balas jasa bagi employers maupun employees baik yang langsung berupa uang (finansial) maupun yang tidak langsung berupa uang (nonfinansial). Sedangkan Handoko (dikutip oleh Gunawan 1998) mengatakan bahwa kompensasi adalah pemberian kepada karyawan dengan pembayaran finansial sebagai balas jasa untuk pekerjaan yang dilaksanakan, sebagai motivator untuk pelaksanaan kegiatan di waktu yang akan datang.

Menurut Werther \& Keith Davies (dikutip oleh Tanjung, 2003) Compensation is what employee receive in exchange of their work. Whether hourly wages or periodic salaries, the personnel department usually designs and administers employee compensation. Begitupula menurut Hasibuan (dikutip 
oleh Tanjung, 2003) kompensasi adalah semua pendapatan yang berbentuk uang atau barang langsung atau tidak langsung yang diterima karyawan sebagai imbalan atas jasa yang diberikan kepada perusahaan.

Berdasarkan PSAK No. 53 Akuntansi Kompensasi berbasis saham, istilah kompensasi mencakup semua imbalan yang diberikan oleh perusahaan kepada pemasok barang atau jasa. Pemasok mencakup pihak karyawan dan non karyawan. Dalam transaksi pemerolehan barang atau jasa, perusahaan dapat menempuh cara kompensasi dengan menerbitkan instrumen ekuitas perusahaan. Sedangkan Pfeffer (2001) mengatakan beberapa mitos mengenai pembayaran yaitu :

1. Labor rates are the same as labor costs

2. Cutting labor rates will lower labor costs

3. Labor costs represent a large portion of a company's total costs

4. Keeping labor costs low creates a potent and sustainable competitive edge

5. Individual incentive pay improves performance

6. People work primarily for the money

Sehingga dapat disimpulkan kompensasi/ balas jasa adalah imbalan jasa yang diberikan kepada karyawan baik yang bersifat finansial maupun non finansial secara adil dan layak sesuai dengan sumbangan karyawan terhadap pencapaian tujuan perusahaan.

\section{Jenis Program Kompensasi}

Menurut Martoyo (2007) paket kompensasi dari seorang manajer terdiri dari tiga komponen :

1. Gaji

2. Tunjangan (tunjangan pensiun, kesehatan)

3. Kompensasi insentif Manajer umumnya menerima kompensasi yang lebih tinggi di perusahaan yang besar dibandingkan di perusahaan yang kecil, dan perusahaan di industri yang sama cenderung untuk bersaing satu sama lain dalam hal kompensasi. Ketiga hal tersebut diatas saling berkaitan, tetapi kompensasi insentif berkaitan dengan fungsi pengendalian manajemen.

Sedangkan jenis kompensasi eksekutif menurut Hitt (2015: 125)

1. Pemberian opsi saham yaitu hak untuk membeli saham di masa depan pada harga yang ditentukan saat ini. Kompensasi ditentukan oleh selisih antara harga opsi dan harga eksekusi. Prinsip dasar yaitu memberikan insentif bagi eksekutif untuk menciptakan kekayaan bagi pemegang saham sebagaimana diukur oleh kenaikan harga pasar dari saham perusahaan. Kelemahannya yaitu tergantung dari harga saham yang tidak bisa menjelaskan seluruh dimensi dari kinerja manajerial.

2. Program saham terbatas yaitu saham yang diberikan kepada eksekutif yang dilarang untuk menjualnya selama periode waktu tertentu. Program ini mungkin juga memasukkan batasan kinerja. Prinsip dasar yaitu mendorong masa jabatan eksekutif yang lebih lama 
dibandingkan dengan bentuk kompensasi lainnya.

Kelemahannya yaitu tidak adanya resiko kerugian bagi eksekutif, yang selalu diuntungkan dan tidak seperti para pemegang saham lainnya.

3. Borgol emas yaitu bonus yang tidak dibayarkan sekaligus namun melalui serangkaian pembayaran tahunan. Jumlah bonus yang ditangguhkan (belum dibayarkan) dianggap hangus ketika eksekutif yang bersangkutan mengundurkan diri. Prinsip dasar menawarkan suatu insentif bagi eksekutif untuk tetap bekerja di perusahaantersebut.Kelemahanny a dengan mendorongpengambilan keputusan yang tidak mau ambil resiko karena resiko kerugian yang ditanggung oleh eksekutif.

4. Parasut emas yaitu para eksekutif mempunyai hak untuk mendapatkan bonus jika mereka kehilangan posisi karena pengambilalihan, pemutusan hubungan kerja, pensiun atau pengunduran diri. Prinsip dasar Menawarkan suatu insentif bagi eksekutif untuk tetap bekerja di perusahaan tersebut. Kelemahannya kompensasi diperoleh tanpa memedulikan apakah kekayaan pemegang saham diciptakan atau tidak. Sama-sama memberikan imbalan baik untuk keberhasilan maupun kegagalan.

5. Pembayaran tunai berdasarkan kinerja internal bisnis menggunakan ukuran keuangan. Merupakan kompensasi bonus didasarkan pada ukuran kinerja akuntansi seperti tingkat pengembalian dan ekuitas. Prinsip dasar meniadakan keterbatasan dari berfokus pada ukuran kinerja berbasis pasar. Kelemahannya yaitu korelasi yang lemah antara ukuran laba dengan penciptaan kekayaan pemegang saham. Laba tahunan tidak mencakup akibat masa depan dari keputusan saat ini.

Dalam pemberian insentif diperlukan suatu planning, menurut Hall (2001) terdapat tiga tipe option plans:

1. Fixed value plans, for which executives receive option of a predetermined value every year, are ideal for companies that set pay according to compensation surveys, but they weaken the link between pay and performance.

2. Fixed number plans, which stipulate the number of option executives will receive over the plan period, provide a much stronger link.

3. The lumpsum megagrant is the most highly leveraged type of grant because it not only fixes the number of option in advance, it fixes the exercise price as well.

\section{Faktor yang Mempengaruhi Kompensasi}

Faktor-faktor yang mempengaruhi perumusan penetapan kompensasi menurut Martoyo (2007):

1. Kebenaran dan keadilan. Hal ini mengandung pengertian bahwa pemberian kompensasi kepada masing-masing karyawan atau kelompok karyawan harus 
sesuai dengan kemampuan, kecakapan, pendidikan dan jasa yang telah ditunjukkan kepada organisasi.

2. Dana Organisasi.

Kemampuan organisasi untuk dapat melaksanakan kompensasi baik berupa "finansial" maupun "nonfinansial" amat tergantung kepada dana yang terhimpun untuk keperluan tersebut. Terhimpunnya dana tersebut sebagai akibat prestasi kerja yang telah ditunjukkan oleh karyawan. Makin besar prestasi kerja, makin besar keuntungan perusahaan, makin besar dana yang terhimpun untuk kompensasi, maka makin baik pelaksanaan kompensasi dan sebaliknya.

3. Serikat karyawan.

Para karyawan yang tergabung dalam suatu serikat karyawan dapat juga mempengaruhi pelaksanaan ataupun penetapan kompensasi dalam organisasi, sebab suatu serikat karyawan dapat merupakan "simbol kekuatan" karyawan dalam menuntut perbaikan nasib, yang perlu mendapatkan perhatian atau perlu diperhitungkan oleh pihak manajemen/pimpinan organisasi,

4. Produktivitas kerja.

Produktivitas kerja karyawan merupakan faktor yang mempengaruhi penilaian atas prestasi kerja karyawan. Sedang prestasi kerja karyawan merupakan faktor yang diperhitungkan dalam penetapan kompensasi. Karena itu produktivitas kerja karyawan ikut mempengaruhi pelaksanaan pemberian kompensasi.

5. Biaya hidup.

Penyesuaian besarnya kompensasi, terutama yang berupa upah/gaji, dengan biaya hidup karyawan beserta keluarganya sehari-hari, harus mendapatkan perhatian pimpinan organisasi.

6. Pemerintah. Fungsi pemerintah untuk melindungi warganya dari tindak sewenang-wenang pimpinan organisasi ataupun perusahaan, dalam pemberian balas jasa karyawan, jelas berpengaruh terhadap penetapan kompensasi. Karena itu pemerintahlah yang ikut menentukan upah minimum ataupun jumlah jam kerja karyawan.

Berdasarkan hasil penelitian Naimah (2003), secara empiris menunjukkan kompensasi eksekutif berhubungan secara signifikan dan positif dengan laba per lembar saham (earning per share) dan penjualan. Hal ini menunjukkan bahwa semakin tinggi penjualan dan laba per lembar saham yang bisa dihasilkan oleh suatu perusahaan, semakin besar pula kompensasi perusahaan tersebut kepada manajer yang memimpin perusahaan.Di samping itu, hasil juga menunjukkan bahwa kompensasi eksekutif berhubungan negatif dan signifikan dengan imbal hasil atas ekuitas (return on equity). Hal ini berarti semakin tinggi imbal hasil ekuitas yang dapat dicapai perusahaan, maka semakin rendah kompensasi yang bisa diberikan perusahaan tersebut kepada eksekutif. 
Penelitian ini tidak berhasil membuktikan bahwa kompensasi eksekutif juga berhubungan dengan imbal hasil saham (stock return) dan pertumbuhan perusahaan.

Penelitian ini juga menunjukkan adanya hubungan antara kompensasi eksekutif dan penjualan. Penjualan yang merupakan proxy ukuran perusahaan juga berhubungan dengan kompensasi, . Hasil penelitian ini juga membuktikan adanya hubungan antara kompensasi eksekutif dengan kinerja perusahaan yang dinyatakan sebagai imbal hasil atas ekuitas (return on equity).

\section{Fungsi Kompensasi}

Kompensasi memiliki beberapa fungsi, menurut Martoyo (2007) diantaranya:

1. Pengalokasian sumberdaya manusia secara efisien.

Fungsi ini menunjukkan bahwa pemberian kompensasi yang cukup baik pada karyawan yang berprestasi baik, akan mendorong para karyawan untuk bekerja dengan lebih baik dan kearah pekerjaan yang lebih produktif.

2. Penggunaan sumber daya manusia secara lebih efisien dan efektif.

Dengan pemberian kompensasi yang tinggi kepada seseorang karyawan mengandung implikasi bahwa organisasi akan menggunakan tenaga karyawan termaksud dengan seefisien dan seefektif mungkin. Sebab dengan cara demikian, organisasi yang bersangkutan akan memperoleh manfaat dan/ atau keuntungan semaksimal mungkin.

3. Mendorong stabilitas dan pertumbuhan ekonomi.

Sebagai akibat alokasi dan penggunaan sumber daya manusia dalam organisasi yang bersangkutan secara efisien dan efektif tersebut, maka dapat diharapkan bahwa sistem pemberian kompensasi tersebut secara langsung dapat membantu stabilisasi organisasi dan secara tidak langsung ikut andil dalam mendorong stabilisasi dan pertumbuhan ekonomi negara secara keseluruhan.

\section{Tujuan Pemberian Kompensasi}

Menurut Martoyo

pemberian kompensasi memiliki beberapa tujuan, diantaranya :

1. Pemenuhan kebutuhan ekonomi. Karyawan menerima kompensasi berupa upah, gaji atau bentuk lainnya adalah untuk dapat memenuhi kebutuhan hidupnya sehari-hari atau dengan kata lain kebutuhan ekonominya. Dengan adanya kepastian menerima upah ataupun gaji tersebut secara periodik, berarti adanya jaminan economic security beserta keluarga yang menjadi tanggungannya.

2. Pengkaitan kompensasi dengan produktivitas kerja. Dalam pemberian kompensasi yang makin baik akan mendorong karyawan bekerja makin produktif. Dengan produktivitas kerja yang tinggi, ongkos karyawan per unit produksi akan 
semakin rendah.

3. Pengkaitan kompensasi dengan sukses perusahaan.

Makin berani suatu perusahaan memberikan kompensasi yang tinggi, makin menunjukkan betapa makin suksesnya suatu perusahaan. Sebab pemberian kompensasi yang tinggi hanya mungkin apabila pendapatan perusahaan yang digunakan untuk itu makin besar.

4. Pengkaitan antara keseimbangan keadilan pemberian kompensasi.

Ini berarti bahwa pemberian kompensasi yang tinggi harus dihubungkan atau diperbandingkan dengan persyaratan yang harus dipenuhi oleh karyawan yang bersangkutan pada jabatan dan kompensasi yang tinggi tersebut. Sehingga ada keseimbangan antara "input" (syarat-syarat) dan "output" (tingginya komepnsasi yang diberikan).

\section{Teori Agensi}

Hubungan agensi ada ketika salah satu pihak (prisipal) menyewa pihak lain (agen) untuk melaksanakan suatu jasa, dan dalam melakukan hal itu, mendelegasikan wewenang untuk membuat keputusan kepada agen tersebut. Dalam suatu korporasi, pemegang saham merupakan prinsipal dan CEO adalah agen mereka. Pemegang saham menyewa CEO dan mengharapkan ia untuk bertindak bagi kepentingan mereka. Di tingkat yang lebih rendah, CEO adalah prinsipal dan manajer unit bisnis adalah agennya. Tantangannya bagaimana cara untuk memotivasi agen sedemikian rupa sehingga mereka akan menjadi sama produktifnya seperti jika mereka adalah pemilik. Salah satu elemen kunci dari teori agensi adalah bahwa prinsipal dan agen memiliki preferensi atau tujuan yang berbeda. Kontrak insentif dalam hal ini pemberian kompensasi akan mengurangi perbedaan preferensi ini. Konflik keagenan muncul dari perbedaan kepentingan antara dua pihak yang terlibat kontrak dalam organisasi, yaitu antara prinsipal dengan agen.

Teori agensi mengasumsikan bahwa semua individu bertindak untuk kepetingan mereka sendiri. Agen diasumsikan akan menerima kepuasan tidak hanya dari kompensasi keuangan tetapi juga dari tambahan yang terlibat dalam hubungan suatu agensi, seperti waktu luang yang banyak, kondisi kerja yang menarik, keanggotaan klub, dan jam kerja yang fleksibel. Scott (2000) menggambarkan program kompensasi eksekutif merupakan salah satu bentuk kontrak keagenan antara perusahaan dengan para eksekutifnya sebagai usaha penyejajaran kepentingan masingmasing.

\section{Kinerja}

Sebuah organisasi merupakan sekumpulan individu yang saling bekerjasama untuk mencapai tujuan yang telah ditetapkan sebelumnya melalui aktivitas-aktivitas tertentu sesuai dengan perannya masing-masing.Penggerak dari organisasi itu adalah sekelompok orang yang berperan aktif terlibat dalam upaya pencapaian tujuan sehingga organisasi selalu berusaha meningkatkan kinerja individu (individual performance).Bila kinerja individu baik, maka diharapkan 
kinerja organisasi akan baik pula, The manager principal concern is to motivate the individual to achieve the organization's objectives in an affective and efficient way. This is performance.

Untuk mencapai tujuan tersebut, ada banyak faktor yang mempengaruhi kinerja karyawan.Karyawan bekerja dengan produktif atau tidak, tergantung pada motivasi, kepuasan kerja, tingkat stress, kondisi fisik perusahaan, sistem kompensasi, desain pekerjaan, aspekaspek ekonomis serta teknis, dan keperilakuan lainnya.

Semua organisasi kemungkinan mengevaluasi atau menilai kerja karyawan dalam beberapa cara. Pada organisasi kecil, evaluasi ini mungkin sifatnya informal. Didalam organisasiorganisasi besar, evaluasi atau penilaian kinerja kemungkinan besar merupakan prosedur yang sifatnya sistematik dimana kinerja sesungguhnya dari semua karyawan manajerial, profesional, teknis, penjualan, dan klerikal dinilai secara formal.

Menurut Mayer dalam As'ad (1991: 499) bahwa kinerja atau prestasi kerja pada umumnya dirumuskan sebagai kesuksesan seseorang dalam melakukan pekerjaan. Vroom dalam As'ad (1991: 60) mengemukakan bahwa kinerja adalah hasil yang dicapai seseorang menurut ukuran yang berlaku pada pekerjaan yang bersangkutan. Tingkat sampai sejauh mana keberhasilan seseorang dalam melakukan tugas pekerjaannya disebut derajat kinerja (Level of performance).

Dikatakan oleh Suyadi (dikutip oleh Supratiningrum, 1999) Performance (kinerja) adalah hasil kerja yang dapat dicapai oleh seorang atau sekelompok orang dalam suatu organisasi, sesuai dengan wewenang dan tanggung jawab masing-masing, dalam rangka upaya mencapai tujuan organisasi bersangkutan secara legal, tidak melanggar hukum dan sesuai dengan moral maupun etika,

Kinerja manajerial merupakan salah satu faktor yang dapat meningkatkan keefektifan organisasi. Menurut Mahoney dkk (1963) dalam Nur Indriantoro (1993), yang dimaksud dengan kinerja manajerial adalah kinerja para individu anggota organisasi dalam kegiatan-kegiatan manajerial, antara lain: perencanaan, investigasi, koordinasi, supervisi, pengaturan staf (staffing), negosiasi dan representasi.

Seseorang yang memegang posisi manajerial diharapkan mampu menghasilkan suatu kinerja manajerial, berbeda dengan kinerja karyawan yang pada umumnya bersifat kongkrit, kinerja manajerial bersifat abstrak dan komplek. Manajer menghasilkan kinerja dengan mengarahkan bakat dan kemampuan, serta usaha beberapa orang lain yang berada di dalam daerah wewenangnya (Mulyadi \& Johny, 1998)

\section{Penilaian Kinerja}

Dalam fungsi manajemen, bila suatu misi telah dituangkan dalam berbagai jenjang perencanaan, maka tindakan selanjutnya adalah melaksanakan sesuai dengan arah dan tujuan yang akan dicapai. Proses pelaksanaan memerlukan pengawasan dan pengawasan itu dilakukan dengan penilaian kinerja (performance appraisal). 
Hilton, Maher \& Selto (2006) Financial performance reflects the achievement of financial goals, such as : Cost control, Revenue growth, Earnings, Residual income. Adding nonfinancial measures to the incentive system, Gets managers to focus on the leading indicators of profit. Gives recognition of the time lags between nonfinancial and financial performance.

Selanjutnya Hilton, dkk (2006) juga mengatakan financial measures of performance tend to be the most objective measures because most organizations have dedicated significant resources to ensure the validity of their financial performance measures. Robert L. Mathis Dan John H. Jackson (1998: 343) mendefinisikan Performance appraisal is the process of evaluating or determining how well employees do their jobs compared with a set of standards and communicating that information those employees.

Dari definisi tersebut mengandung maksud bahwa penilaian kinerja sangatlah penting bagi kalangan karyawan, metode-metode penilaian yang digunakan, dan cara hasil-hasil yang dikomunikasikan dapat memiliki pengaruh positif maupun negatif terhadap moral kerja karyawan. Pada saat penilaian-penilaian kinerja dipakai untuk tindakan disiplin, kenaikan-kenaikan gaji, promosi-promosi, pemecatan-pemecatan, atau pemberhentian sementara. Definisidefinisi tersebut secara umum menggambarkan bahwa penilaian kinerja merupakan sebuah proses dimana perusahaan menilai secara formal kinerja karyawannya. Hal ini juga ditekankan dalam beberapa definisi tersebut adalah standar penilaian dan umpan balik dari karyawan yang dinilai.

Sementara itu menurut Gomes (2000: 142) ukuran kinerja mencakup beberapa tipe kriteria performansi kinerja yang didasarkan atas deskripsi perilaku yang spesifik, yaitu:

1. Quantity of work, yaitu jumlah hasil kerja yang dia dapat dalam suatu periode waktu yang ditentukan.

2. Quality of work, yaitu kualitas kerja yang dicapai berdasarkan syarat-syarat kesesuaian dan kesiapannya.

3. Job knowledge, luasnya pengetahuan mengenai pekerjaan dan ketrampilannya.

4. Creativeness, yaitu keaslian gagasan-gagasan yang dimunculkan dan tindakantindakan untuk menyelesaikan persoalan-persoalan yang timbul.

5. Cooperative, yaitu kesediaan untuk bekerja sama dengan orang lain (sesama anggota organisasi).

6. Dependability, yaitu kesadaran dan dapat dipercaya dalam hal kehadiran dan penyelesaian kerja.

7. Initiative, yaitu semangat untuk melaksanakan tugas-tugas baru dan dalam memperbesar tanggung jawabnya.

8. Personal qualities, yaitu menyangkut kepribadian, kepemimpinan, keramahtamahan dan integrasi pribadi.

Sedangkan kriteria kinerja menurut Martoyo (2007):

1. Kriteria keuangan : margin kontribusi, laba unit bisnis langsung, laba unit bisnis yang dapat dikendalikan, laba sebelum 
pajak, laba bersih, ROI

2. Periode waktu : kinerja tahunan, multi tahun

3. Kriteria non keuangan: pertumbuhan penjualan, pangsa pasar, kepuasan pelanggan, kualitas, pengembangan produk baru, pengembangan karyawan, tanggungjawab publik

4. Tolok ukur untuk perbandingan: anggaran laba, kinerja masa lalu, kinerja pesaing

5. Pendekatan penentuan bonus: berdasarkan rumus, subjektif atau keduanya

Hall (2000) mengatakan bahwa metode kompensasi untuk memotivasi manajer agar berfokus pada tujuan jangka panjang, memerlukan ikatan/pertalian dengan ukuran kinerja yang memperlihatkan masa depan daripada masa lalu. Pengukuran sendiri ada dua :

1. Tradisional: penggunaan accounting profit yang mengukur masa lalu, bukan masa depan

2. Stock price: mengukur masa depan. Hal ini memperkirakan bagaimana aksi saat ini akan mempengaruhi profit masa depan perusahaan. Forecast tidak sepenuhnya akurat, tetapi karena investor memiliki uang mereka sendiri dalam jalur tersebut, mereka sangat menekankan untuk membaca masa depan dengan benar. Hal ini membuat stock market merupakan prediktor terbaik untuk kinerja

Reward berbasis kinerja
memberi dua manfaat: memberi informasi dan memberikan motivasi (Mulyadi \& Johny, 1998).

\section{Kompensasi sebagai Alat Peningkatan Kinerja}

Beberapa motivasi yang mendasari para manajer melakukan motivasi entrenchment/ berkubu menurut Brochet dan Gildao 2004 (dikutip oleh Suranta \& Merditusti 2004) antara lain adalah (1) kompensasi yang diterima manajer tidak sesuai dengan kinerja yang mereka hasilkan (Job Security Hypothesis), (2) jumlah saham yang dimiliki para manajer (3) tidak adanya mekanisme monitoring yang efektif, (4) pasar modal yang sangat kompetitif dimana para manajer akan melakukan praktek income smoothing dengan cara meningkatkan kinerja pada tahun dimana perusahaan mengalami kinerja yang buruk "poor performance" dan melakukan "safety performance" pada tahun dimana perusahaan mengalami kinerja yang sangat baik, (5) masa jabatan CEO dimana semakin lama masa jabatan CEO dapat mempengaruhi keputusan yang diambil oleh para dewan direksi dan mempengaruhi mekanisme corporate governance, (6) CEO berperan dalam pengungkapan dan penyajian laporan keuangan, sehingga mereka akan lebih berpengaruh daripada dewan direksi.

Rappaport (2001) mengatakan bahwa agar kompensasi insentif bekerja, corporate boards harus memilih pengukuran dan level kinerja yang tepat. Pada prinsipnya, stock option pekerja, pengukuran dan kinerja yang tepat untuk eksekutif perusahaan adalah yang bertanggungjawab untuk perusahaan secara keseluruhan. Setelah itu, nilai stock option didorong oleh harga saham, dimana komponen terbesar adalah total return shareholders. Beberapa manajer 
memprotes ekspektasi shareholders yang sangat tidak realistis, tetapi banyaknya bukti tidak mendukung kesimpulan tsb.

Kohn (2001a) juga menyebutkan mengapa banyak eksekutif percaya/mengandalkan program insentif. Hal tersebut disebabkan karena sedikit orang mengambil waktu/ kesempatan untuk menguji hubungan antara program insentif dengan program produktivitas dan moral di tempat kerja. Rewards mengatasi masalah sementara, jadi terlihat bahwa masalah terselesaikan. Hal ini lebih sulit untuk menandai kesalahan yang mereka sebabkan dalam waktu yang lama. Wolters (dikutip oleh Kohn 2001b) mengatakan It is comforting to believe that incentives fail only for incidental reason, such as that they are mis-used. Begitupula dengan Baker (dikutip oleh Kohn 2001b) juga mengatakan They are offered for the wrong behaviour. Kohn (2001b) mengatakan Incentive plans must fail, because they are based on a patently inadequate theory of motivation.

$$
\text { Agar dalam pemberian }
$$
kompensasi tidak mengalami permasalahan, maka perlu diperhatikan beberapa hal tentang pay yaitu sebagai berikut :

\section{Pay is not a motivator}

Meskipun seseorang pada intinya merisaukan gajinya, hal ini tidak menjamin/ membuktikan bahwa uang adalah motivasi. Tidak ada perusahaan yang berbasis asumsi bahwa membayar seseorang akan lebih mendorong mereka untuk bekerja lebih baik, dan dalam jangka panjang, lebih banyak bekerja. Frederick Herzberg,mengasumsikan, hanya karena jumlah uang terlalu kecil dapati mengganggu/ menjengkelkan dan tidak memotivasi yang tidak berrati uang yang lebih banyak akan meningkatkan kepuasan, sedikit meningkatkan motivasi.hal ini masuk akal untuk mengasumsikan bahwa jika seseorang mengambil take-home pay dipotong separuh, moral nya akan cukup menderita untuk mengurangi/meruntuhkan kinerja.

2. Rewards punish

Banyak manajer memahami bahwa penggunaan kekerasan/paksaan dan ketakutan merusakkan motivasi dan menciptakan pertentangan, pertahanan, dan kemarahan. Hukuman dan imbalan adalah dua sisi koin. Rewards/ imbalan mempunyai efek hukuman tetapi seperti hukuman palsu, adalah bersifat manipulasi. "kerjakan ini atau kamu akan mendapatkannya" adalah sangat berbeda dengan "kerjakan ini sekarang atau akan terjadi sesuatu padamu." dalam kasus insentif, imbalan itu sendiri adalah keinginan yang sangat tinggi; tetapi hal itu membuat bonus kontingen dalam perilaku yang pasti, dan pengalaman tersebut menjadi terkendali seperti yang diasumsikan sebagai kualitas hukuman. Lebih jauh, tidak menerima imbalan yang diharapkan juga tidak berbeda dengan menjadi hukuman.

3. Rewards rupture/memecah relationship 
Hubungan diantara pekerja sering merupakan korban pertarungan/perjuangan untuk imbalan. Jalan pasti untuk merusak kerjasama dan keunggulan organisasional, adalah untuk memaksa seseorang untuk berkompetisi untuk imbalan atau penghargaan atau rangking mereka terhadap yang lain. Ketika pekerja berkompetisi untuk insentif yang terbatas, mereka akan seperti memulai untuk melihat yang lain sebagai penghalang/rintangan untuk kesuksesan mereka sendiri. Tetapi hal yang sama dapat terjadi dengan penggunaan setiap rewards, memperkenalkan kompetisi hanya membuat hal buruk lebih buruk. Hubungan antara supervisor dan bawahannya dapat juga gagal dengan besarnya insentif.

4. Rewards ignore reason

Dalam rangka menyelesaikan masalah ditempat kerja, manajer harus memahami apa yang menyebabkan mereka. Apakah pekerja tidak mampu disediakan untuk permintaan atas pekerjaan mereka? Apakah pertumbuhan jangka panjang menjadi korban untuk memaksimalkan return jangka pendek? Apakah pekerja tidak bersedia untuk bekerjasama secara efektif? Apakah organisasi mempunyai hirarki yang kaku sehingga karyawan terintimidasi mengenai pembuatan rekomendasi dan merasa tidak berkekuatan dan marah? Setiap situasi ini meminta untuk respon yang berbeda.

Lebih lanjut, manajer sering menggunakan sistem insentif sebagai pengganti/ substitusi untuk memberikan pekerja apa yang mereka perlukan untuk mengerjakan pekerjaan yang baik. Pfeffer (2001) mengatakan beberapa saran mengenai pembayaran kompensasi, yaitu:

1. Disarankan agar manajer menjaga dengan baik perbedaan antara labor rates dan labor costs straight. Perlu diingat bahwa hanya labor costs dan bukan labor rates adalah dasar untuk kompensasi.

2. Manajer dapat memperjuangkan mitos bahwa seseorang pada dasarnya dimotivasi oleh uang dengan cara penekanan dan tidak memerankan hal tersebut sebagai hal utama yang didapat saat bekerja disuatu perusahaan.

3. Manajer juga harus mempertimbangkan bahwa pembayaran mempunyai komponen substantif dan simbolik. Hal ini menunjukkan apa dan siapa dalam organisasi yang dinilai, pembayaran juga merefleksikan dan membantu penentuan budaya organisasi.

4. Manajer juga harus mempertimbangkan metode yang lain disamping pembayaran untuk penilaian perusahaan dan berfokus pada perilaku.

Sedangkan Wolters (dikutip oleh Kohn 2001b) Incentives are neither all good nor all bad. Although not the right answer in all cases, they can be highly effective motivational tools and should be 
employed under the appropriate circumstances. Amabile (dikutip oleh Kohn 2001b) It would be a mistake to believe thet reward and recognition must always have a negative effect on performance or that creative people cannot be motivated by both money and interest in the work itself. Selanjutnya Amabile (dikutip oleh Kohn 2001b) juga mengatakan "Intrinsic motivation being motivated by challenge and enjoyment, is essential to creativity. But extrinsic motivation being motivated by recognition and money, doesn't necessarily hurt.

Di dalam pemberian kompensasi Husnan (dikutip oleh Kusuma \& Wahyuddin, 2006) perlu diperhatikan prinsip keadilan. Keadilan bukan berarti bahwa segala sesuatu mesti dibagi samarata. Keadilan harus dihubungkan antara pengorbanan (input) dengan penghasilan (output). Input dari suatu jabatan ditunjukkan dari persyaratanpersyaratan (spesifikasi) yang harus dipenuhi oleh orang yang memangku jabatan tersebut. Semakin tinggi persyaratan yang diperlukan, semakin tinggi pula penghasilan (output) yang diharapkan.Output ini ditunjukkan dari upah yang diterima.Diana (2003) menyebutkan kompensasi semakin meningkat terjadi saat ukuran kinerja komprehensif (finansial dan non finansial) dikombinasikan dengan partisipasi anggota dalam setting target kinerja meningkat Dari definisi tersebut diketahui bahwa kompensasi dalam hal ini insentif dapat menjadi motivasi yang efektif dalam peningkatan kinerja.

Kompensasi CEO biasanya didiskusikan oleh Komite Kompensasi Dewan Komisaris. Terjadi perdebatan mengenai kompensasi CEO, Apakah CEO dibayar terlalu banyak? Beberapa usulan yang dibuat untuk memastikan Dewan Komisaris bertindak untuk kebaikan pemegang saham dan tidak bekerja dibawah tekanan CEO :

a. Cegah direktur untuk tidak menjual saham mereka selama masa jabatannya guna mendorong mereka untuk menanyakan pertanyaan-pertanyaan "sulit" kepada CEO tanpa rasa takut bahwa hal itu akan mempengaruhi harga saham jangka pendek

b. Tetapkan batasan-batasan tegas mengenai masa jabatan direktur guna mencegah mereka menjadi terlalu terlibat dengan manajemen

c. Adakan tinjauan kinerja tahunan dari para direktur

d. Hindarkan menjadikan CEO korporat sebagai ketua dewan komisaris

\section{Kesimpulan}

Kesimpulan yang dapat diambil adalah sebagai berikut:

1. Kompensasi diberikan untuk mengatasi masalah dalam teori agensi, yaitu perbedaan kepentingan antara pemilik dan agennya.

2. Sistem kompensasi yang dirancang organisasi bertujuan untuk memotivasi karyawan untuk meningkatkan kinerjanya dan mempertahankan karyawan yang kompeten.

3. Agar kompensasi insentif bekerja, corporate boards harus memilih pengukuran dan level kinerja yang tepat. Sistem pengukuran 
kompensasi ada dua yaitu tradisional: penggunaan accounting profit yang mengukur masa lalu, bukan masa depan dan stock price yang mengukur masa depan.

\section{Daftar Pustaka}

Anthony, Robert and Govindarajan. 2005. Sistem Pengendalian Manajemen.Jakarta: Salemba Empat

As'ad, M., 1991.“Seri Ilmu Sumber Daya Manusia: Psikologi Industri" Edisi Keempat. Cetakan Keenam. Liberty. Yogyakarta.

Davis, Keith and John W. Newstrom, 1992. Human Behaviour at Work: Organizational Behaviour. Secound edition. Singapore. McGraw-Hill International Editions.

Diana, Nur. 2003. Analisis Hubungan Kompleksitas Organisasi, Keterlibatan Tim, Diversitas Ukuran Kinerja, Besar Kompensasi, Partisipasi terhadap Kinerja Tim. Simposium Nasional Akuntansi. 2003. Surabaya

Gunawan, Ade. 1998. Memanage Performance Karyawan melalui pemberian kompensasi. Jurnal Ilmiah Manajemen dan Bisnis, Program Studi Manajemen, Fakultas Ekonomi, Universitas Muhammadiyah Sumatera Utara, Vol. 2 No. 02, Oktober 2002
Hansen, DR. \& Mowen, MM. 2013. Managerial Accounting, $8^{\text {th }}$ Edition, United States: Thomson South Western,

Hall, Brian. 2001. What You Need to Know about Stock Option. USA: Harvard Business School Publishing Corporation.

Hilton, Maher \& Selto.2006. Cost Management: strategies for business decision, 3th edition. Mc graw Hill/ Irwin

Hitt. MA, Ireland RD. \& Hosskison, RE.2015. Strategic Management Competitiveness \& Globalization. 11th edition. Cengage Learning. United States.

Kusuma \& Wahyuddin, Pengaruh Motivasi Karyawan, PPKP, dan persepsi keadilan atas kompensasi terhadap kepuasan kerja karyawan pada PT Bank Negara Indonesia (Persero) Tbk Kantor Cabang Surakarta

Pernyataan Standar Akuntansi Keuangan, Ikatan Akuntan Indonesia, 2015, Akuntansi Kompensasi Berbasis Saham

Preffer. 2001. Six Dangerous Myths About Pay. USA: Harvard Business School Publishing Corporation.

Rappaport, Alfred. 2001. New Thinking How To Link Executive Pay With Performance. USA: Harvard Business School Publishing Corporation.

Scott, W. R. 2000. Financial Accounting Theory.Second Edition. Ontario: Prentice Hall Canada Inc.

Suprantiningrum \& Zulaikha. 2003. Pengaruh Total Quality Management terhadap kinerja 
manajerial dengan sistem pengukuran kinerja dan sistem penghargaan (reward) sebagai variabel moderating (Studi empiris pada hotel di Indonesia). Simposium Nasional Akuntansi VI. Surabaya

Suranta \& Merdistuti. 2004. Income Smoothing, Tobin's Q, Agency Problems dan Kinerja Perusahaan.
Simposium Nasional Akuntansi VII. Denpasar, Bali.

Tanjung, Andri. 2003. Pengaruh Kompensasi terhadap Motivasi Kerja Karyawan Bagian Personalia PT Agronesia Divisi Industri Makanan dan Minuman Bandung.Skripsi. Jurusan Manajemen, Fakultas Bisnis dan Manajemen Universitas Widyatama, Bandung. 